\title{
Line Drawing and the Bankruptcy Discharge: Why Prepetition Stipulations Are Enforceable but Prepetition Waivers Are Not ${ }^{*}$
}

\section{INTRODUCTION}

"The legal effect of the discharge is powerful in its simplicity: the debtor is freed from the obligation to pay prebankruptcy debts."1 Although the consumer debtor has no right to discharge, it is regularly granted to debtors who have not run afoul of any of the provisions of $\$ 727(\mathrm{a}),{ }^{2}$ which is "the heart of the fresh start provisions." ${ }^{3}$ When the debtor is freed from liability for prepetition debts, the debtor's creditors suffer the loss of nonpayment. Therefore, creditors desire a bankruptcy system that does not overly favor debtors. In general, the current Bankruptcy Code represents an appropriate balance between prodebtor and procreditor views. Despite the balance, creditors continue in their attempts to circumvent the bankruptcy discharge, which has the potential to erode the effectiveness of a debtor's fresh start. Because the automatic stay and discharge injunction prohibit the types of postpetition actions a creditor can take to collect a debt, creditors tend to focus their efforts on prepetition preventive measures. The scope of this Comment, therefore, is limited to prepetition attempts creditors make to transform a debt that is otherwise dischargeable into one that is nondischargeable.

In particular, the analysis of this Comment is confined to Chapter 7 consumer cases-the most common type of bankruptcy case. ${ }^{4}$ This

\footnotetext{
Kristin L. Ballobin. J.D. 2010, University of Kansas School of Law; M.S. \& B.S. 2007, Kansas State University. I would like to thank Professor Stephen Ware for his guidance and comments in the development of this Comment. I would also like to acknowledge the assistance of Pat Edwards and the Kansas Law Review staff in the writing and editing process. Finally, I would like to thank my friends and family for their unwavering support in my educational and professional endeavors.

1. Charles Jordan Tabb, The Scope of the Fresh Start in Bankruptcy: Collateral Conversions and the Dischargeability Debate, 59 GEO. WASH. L. REV. 56, 56 (1990).

2. See 11 U.S.C. $\$ 727(a)(1)-(12)$ (2006).

3. S. REP. No. 95-989, at 98 (1978), reprinted in 1978 U.S.C.C.A.N. 5787, 5884.

4. For example, the Central District of Illinois reports that in 2009 a total of 10,788 bankruptcy cases were filed, of which 8475 were Chapter 7 cases-over $78 \%$ were Chapter 7. Statistics, U.S. BANKR. CT.: CENT. DISTRICT OF ILL., http://www.ilcb.uscourts.gov/CMECF/filinGsold/calendar_
} 
Comment demonstrates that both a prepetition waiver of discharge in total and a prepetition waiver of discharge of a specific debt are unenforceable. Further, public policy and the purpose behind the Bankruptcy Code support the unenforceability of such waivers. Also, the Comment discusses the enforceability of prepetition stipulations in a later bankruptcy proceeding and the general collateral estoppel effect that state law will grant to those stipulations. In general, bankruptcy courts should grant issue-preclusive effect to state court stipulations because it promotes judicial economy and validates the time the state court expended in drafting them. The main objective of this Comment is to analyze and compare prebankruptcy waivers and stipulations so that the enforcement of one over the other can be justified satisfactorily.

Part II of this Comment offers a quick overview of the purpose behind the bankruptcy system and the background necessary to grasp the effect discharge has on debtors and creditors. Part III discusses prepetition waivers and prepetition stipulations in state court judgments. In relation to prepetition stipulations, Part III discusses the types of debts that are excepted from discharge, the United States Supreme Court's limited guidance on collateral estoppel in dischargeability proceedings, and the jurisdiction of courts over the discharge exceptions. Part IV analyzes the enforceability of prepetition waivers and stipulations. It concludes that prepetition waivers of discharge are not and should not be enforceable, while also concluding that prepetition stipulations should be enforceable and entitled to collateral estoppel effect. Part IV draws a distinction between prepetition waivers and stipulations and demonstrates why they should be treated differently in bankruptcy dischargeability proceedings.

\section{OVERVIEW OF THE BANKRUPTCY PROCESS}

As the Supreme Court has long recognized, the bankruptcy process "gives to the honest but unfortunate debtor ... a new opportunity in life and a clear field for future effort, unhampered by the pressure and discouragement of pre-existing debt." Two recurring themes have grown from the preceding statement. First, to seek relief under the

stats.aspx (last visited Oct. 14, 2010). Also, the Central District of California reports that from January 2009 to December 2009, a total of 98,469 cases were filed, of which 75,817 cases were Chapter 7-approximately 77\% were Chapter 7. 2009 Filings for Central District, U.S. BANKR. CT.: CENT. DISTRICT OF CAL., http://www.cacb.uscourts.gov/cacb/statistics.nsf/DistrictSumRep? ReadForm\&Year=2009 (last visited Oct. 14, 2010).

5. Local Loan Co. v. Hunt, 292 U.S. 234, 244 (1934). 
Bankruptcy Code, the debtor must be "honest but unfortunate." Second, the purpose of the bankruptcy process is to grant the debtor a fresh start. ${ }^{7}$ A debtor takes advantage of bankruptcy by filing a petition, which is sometimes referred to as "an order for relief" by the Code. ${ }^{8}$ Once the filing fee has been paid, the petition is considered "filed" and "[a]t that instant, a bankruptcy estate is created and an automatic stay on all collection actions against the debtor, [and] the debtor's property" is in effect. ${ }^{9}$

Once the debtor has completed the bankruptcy process, the court will generally grant the debtor a discharge pursuant to $\S 727(\mathrm{a})$ of the Bankruptcy Code. Although the term is not specifically defined in the Code, "a discharge ... discharges the debtor from all debts that arose before the date" the bankruptcy petition was filed. ${ }^{10}$ However, the practical effects of the discharge are covered more fully in $\S 524(a)$. This section, among other purposes, indicates that the discharge "operates as an injunction against the commencement or continuation of an action ... to collect [or] recover... any such debt as a personal liability of the debtor."11 The previous injunction is permanent and will prevent a creditor from later asserting that the debtor is still responsible for payment. ${ }^{12}$ The effect of the discharge, therefore, is sweeping.

As stated above, the bankruptcy system has been created to assist "the honest but unfortunate debtor." 13 The negative implication of the Supreme Court's statement is that the Bankruptcy Code will not assist a dishonest debtor, and numerous sections have been included in the Code

6. Id.

7. Id. ("One of the primary purposes of the Bankruptcy Act is to "relieve the honest debtor from the weight of oppressive indebtedness, and permit him to start afresh free from the obligations and responsibilities consequent upon business misfortunes." (quoting Williams v. U.S. Fid. \& Guar. Co., 236 U.S. 549, 554-55 (1915))).

8. Elizabeth Warren \& Jay LaWrence Westbrook, The LaW of Debtors and CREDITORS: TEXT, CASES, AND PROBLEMS 115 (6th ed. 2009) ("In order to begin a bankruptcy case, the debtor files a petition. The petition is the basic register for bankruptcy relief ...."); see also 11 U.S.C. § 301(b) (2006) ("The commencement of a voluntary case under a chapter of this title constitutes an order for relief ....").

9. WARREN \& WESTBROOK, supra note 8, at 116.

10. 11 U.S.C. $\$ 727$ (b) (emphasis added).

11. Id. §524(a)(2).

12. See, e.g., Lone Star Sec. \& Video, Inc. v. Gurrola (In re Gurrola), 328 B.R. 158, 175 (B.A.P. 9th Cir. 2005) (stating that the discharge injunction protects the debtor from personal liability). This case is also a good example of debtors' misunderstanding regarding the effect and extent of the discharge injunction. Id. at 160 ("Ignorance. Pure ignorance. The debtor was amazingly ignorant of the legal consequences of his bankruptcy discharge.").

13. Local Loan Co. v. Hunt, 292 U.S. 234, 244 (1934). 
to prevent such a possibility. ${ }^{14}$ Because the underlying purpose of the Code is to give the honest debtor a fresh start, many creditors, especially unsecured creditors, end up with the bad end of the deal. Therefore, some creditors have attempted to circumvent the discharge provisions of the Code by requiring the debtor to waive discharge of a specific debt long before the debtor even contemplates filing for bankruptcy. Other creditors file a prebankruptcy lawsuit against the debtor and get a state court judgment or consent decree entered. These prebankruptcy actions and their enforceability (and authority) are the subject of Parts III and IV of this Comment.

\section{DISCUSSION OF PREBANKRUPTCY ACTIONS BY CREDITORS}

\section{A. Prepetition Waivers of a Specific Debt}

Waivers of dischargeability of a specific debt are attempted frequently in prebankruptcy proceedings. Undoubtedly, prepetition waivers of dischargeability are desirable in agreements and court judgments because the creditor wants assurance that the debtor will be required to pay the debt and not escape that obligation by filing for bankruptcy. Therefore, the creditor is seeking waiver of a single debt rather than a waiver of discharge of all debts. A creditor, for example, may negotiate a term into an agreement or judgment that plainly states: "The debts incurred in this agreement are nondischargeable in bankruptcy." Although parties can include prepetition waivers in virtually any settlement agreement, ${ }^{15}$ this Comment refers to two contexts where these waivers are recurring.

14. See, e.g., 11 U.S.C. § 523(a)(2)(A) (disallowing a debtor to discharge any debts obtained by fraud); id. § 727(a)(2) (withholding discharge when the debtor has defrauded an officer of the estate); id. $\S 707(b)(1)$ (allowing dismissal if "the granting of relief would be an abuse of the provisions of this Chapter"); see also Grogan v. Garner, 498 U.S. 279, 279 (1991) (stating that "the Code limits the opportunity for a completely unencumbered new beginning to the honest but unfortunate debtor by exempting certain debts from discharge").

15. See, e.g., Herz v. Steil (In re Steil), Bankr. No. 05-02079, Adv. No. 05-9108, 2006 WL 2662694, at *1-2 (Bankr. N.D. Iowa Aug. 14, 2006). The debtors entered into a lease agreement for a convenience store with the plaintiff. $I d$. at $* 1$. Debtors suddenly closed the business and failed to remit any payment to the plaintiff. $I d$. at $* 2$. The parties then entered into a hand-written settlement agreement, which stated that the "agreement is binding by its signer and cancels all leases and contracts made prior to today [sic] agreement. This agreement is not to be included in any Bankruptcy Discharge." Id. 


\section{Marital Separation Agreements and Divorce Decrees}

One area of the law where a prepetition waiver of the dischargeability of a certain debt arises is in the context of marital settlement agreements. Divorce proceedings can be difficult and protracted for the parties involved. One common component of these settlement agreements is support obligations. Support obligations commonly include spousal and child support, where a monthly payment is made directly to the ex-spouse in a predetermined amount as set by the marital settlement agreement. ${ }^{16}$ In drafting a marital settlement agreement, an attorney may include a provision that attempts to make the agreed obligations nondischargeable in bankruptcy. Not surprisingly then, "[b]ankruptcy law, with its underlying policy to provide the honest debtor with a fresh start, frequently collides with divorce law and the mutual obligations that arise from dissolution of a marriage."17

In Lewis v. Trump (In re Trump), one attempt at a prepetition waiver was included in a marital settlement and separation agreement's "General Provisions," indicating that " $[\mathrm{t}] \mathrm{he}$ provisions and obligations contained herein are to be considered as not dischargeable in bankruptcy." "18 Under the agreement, the ex-husband agreed to pay child support and, under another section titled "Assumption of Debts and Liabilities," agreed to make monthly payments on a second mortgage, even though his ex-wife would retain the residence. ${ }^{19}$ When the debtor ex-husband filed for bankruptcy, the ex-wife filed a complaint to determine the dischargeability of the debts that had been agreed upon in their marital settlement agreement. ${ }^{20}$ Specifically, the ex-wife urged the court to honor the waiver of discharge contained in the agreement so that the debtor ex-husband would be barred from discharging those debts. ${ }^{21}$ The court concluded that "prepetition agreements to waive the benefits of a bankruptcy discharge are void, and this Court is not bound by this language.",22

16. Daniel A. Austin, For Debtor or Worse: Discharge of Marital Debt Obligations Under the Bankruptcy Abuse Prevention and Consumer Protection Act of 2005, 51 WAYNE L. REV. 1369, 1382 (2005).

17. Lewis v. Trump (In re Trump), 309 B.R. 585, 591 (Bankr. D. Kan. 2004).

18. Id. at 590 .

19. Id. at 589 .

20. Id. at $588-89$.

21. Id. at 593 .

22. Id. 
In another case, Cotten v. Cotten (In re Cotten), the parties attempted to insert a prepetition waiver of discharge into a consensual divorce decree. ${ }^{23}$ The decree mandated that the ex-husband would make second mortgage payments on behalf of his ex-wife and that "such obligation shall ... not [be] dischargeable in bankruptcy." 24 Ultimately, the court did not determine whether the provision was enforceable, although it agreed with the ex-husband that such waivers had been held unenforceable in other jurisdictions. ${ }^{25}$ Instead, the court concluded that it "need not decide whether the provision is enforceable" as other grounds existed for making the debt nondischargeable. ${ }^{26}$

Lastly, in Hester v. Daniel (In re Daniel), the debtor-wife and plaintiff-husband entered into a settlement agreement incorporated into a divorce decree. ${ }^{27}$ As a part of the settlement, the debtor was required to pay half of what the parties owed in credit card debt, totaling $\$ 17,303.24 .^{28}$ Further, the agreement specifically provided:

The Defendant expressly waives her right to discharge the debt to the Plaintiff as set forth herein under any of the United States Bankruptcy laws and the Defendant expressly agrees to not list or include the indebtedness to the Plaintiff as set forth herein on any Chapter 7 or Chapter 13 Bankruptcy that she may file, it being the express intent of the parties that said indebtedness not be dischargeable under the Bankruptcy laws of the United States. ${ }^{29}$

The defendant made a total of three payments and subsequently filed for bankruptcy. ${ }^{30}$ The plaintiff filed an "Objection to Dischargeability," claiming that the debtor had waived her right to discharge the obligations to plaintiff in the prior settlement agreement. ${ }^{31}$ The plaintiff did not convince the bankruptcy court that the waiver provisions of the agreement were enforceable. ${ }^{32}$ The court concluded that "pre-petition waivers of protection afforded by a bankruptcy case" were not permitted

23. 318 B.R. 583, 585 (Bankr. W.D. Okla. 2004).

24. Id.

25. Id. at 587 ("Certainly, waivers of discharge have been held to be unenforceable.").

26. Id. at 586-87 (finding that "the parties' shared intent at the time of the divorce [was] that the Defendant's obligation was for support" and therefore was nondischargeable under 11 U.S.C. $\S 523(\mathrm{a})(5)(2006))$.

27. 290 B.R. 914, 915 (Bankr. M.D. Ga. 2003).

28. Id. at $915-16$.

29. Id. at 916 .

30. Id.

31. Id. at 915,919 .

32. Id. at 919 . 
by courts. ${ }^{33}$ Even with the above careful drafting in the settlement agreement, the court still did not uphold the prepetition waiver. ${ }^{34}$

\section{Attorney's Fees}

As discussed in Part II, the bankruptcy discharge removes any personal liability to pay a prepetition debt. ${ }^{35}$ Generally, any attorney's fees that the debtor has incurred, such as prepetition bankruptcy attorney's fees, as well as any other attorney's fees that were owed before the case was filed, will be discharged at the close of the bankruptcy case. ${ }^{36}$ As a result, "[a]bsent a specific exception to discharge under $\S 523$, the lawyer who furnishes pre-petition bankruptcy services and who is unpaid for such services is in the same boat with other unpaid pre-petition creditors." ${ }^{, 37}$ Attorneys, of course, dislike such an outcome, and some commentators have called for a reform of $\S 523(\mathrm{a})$ to include an exception for attorney's fees. ${ }^{38}$ However, because the majority of courts hold that prepetition attorney's fees are dischargeable, ${ }^{39}$ some attorneys have attempted to require a waiver of dischargeability of any debts incurred in representing the debtor before the petition is filed.

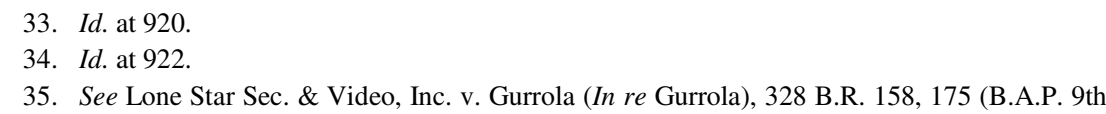
Cir. 2005).

36. In re Nieves, 246 B.R. 866,872 (Bankr. E.D. Wis. 2000).

37. Id.

38. See Kerry Haydel Ducey, Note, Bankruptcy, Just for the Rich? An Analysis of Popular Fee Arrangements for Pre-petition Legal Fees and a Call to Amend, 54 VAND. L. REV. 1665, 1699 (2001) ("Congress must amend $\S 523$ of the Bankruptcy Code to exempt unpaid, pre-petition bankruptcy attorney's fees from discharge.”); Joshua D. Morse, Comment, Public Policy Is Never a Substitute for Statutory Clarity: Rejecting the Notion that Pre-petition Attorney-Fee Debts Are Nondischargeable in Chapter 7 Bankruptcies, 40 SANTA ClARA L. REV. 575, 606-07 (2000) (proposing that Congress "address the issue of dischargeability of pre-petition attorney-fee debts"); see generally James L. Neher, Comment, Rethinking the Discharge of Pre-petition Attorney Fees in Chapter 7 Bankruptcy: A Debtor Oriented Perspective, 6 D.C. L. Rev. 91 (2001) (advocating "the minority view" that "attorney fees in connection with preparing and filing a bankruptcy are not dischargeable whether prepaid or not, as long as they are not excessive").

39. See, e.g., Hessinger \& Assocs. v. U.S. Tr. (In re Biggar), 110 F.3d 685, 688 (9th Cir. 1997) ("Section 523's failure to except debts for attorneys' fees from the Code's discharge provisions leads us to conclude that the debts at issue in this case are dischargeable."); In re Nieves, 246 B.R. at 872 (stating that "[t]he great weight of authority holds that a chapter 7 discharge covers attorney's fees owed by a debtor for services involved in preparation for filing the bankruptcy case"); In re Martin, 197 B.R. 120, 127 (Bankr. D. Colo. 1996) ("Had Congress intended to create an exception to discharge for unpaid attorney fees presumably it would appear in $\$ 523 . ") ;$ see also Neher, supra note 38, at 95-96 (discussing the minority view). 
For example, in In re Nieves, the debtor and his wife met with an attorney to assist them in their decision whether to file for bankruptcy. ${ }^{40}$ Due to the urgency of their situation, the attorney suggested that they file immediately and discussed two options for payment of legal fees in connection with the case. ${ }^{41}$ The first option required the debtors to make a full up front payment before they filed the petition. ${ }^{42}$ The second option required a monthly payroll deduction that would begin after they filed the bankruptcy petition. ${ }^{43}$ The debtors chose the second option and signed an agreement under which the debtors would be personally liable postpetition in the event that the deductions were not forwarded to the attorney. ${ }^{44}$ After examination of the bankruptcy case, the U.S. Trustee challenged the reasonableness of the attorney's fees. ${ }^{45}$ The bankruptcy court then concluded that prepetition attorney's fees were dischargeable and that " $[\mathrm{t}] \mathrm{he}$ provision in the agreement... which obligated the debtors to pay the entire fee [was] unenforceable." 46

The debtor, in Marra, Gerstein \& Richman v. Kroen (In re Kroen), allegedly made an oral representation to his attorney, who had been representing him in a matrimonial matter spanning several years, that he would not discharge the attorney's bill in bankruptcy. ${ }^{47}$ The debtor denied making the statement, pointing to his financial deterioration during the years of the divorce and the large amount of fees he owed to the attorney: $\$ 43,166$ in total and $\$ 14,343$ at the time of his bankruptcy filing. ${ }^{48}$ The bankruptcy court, with an attempt at humor, concluded, "the representation of waiver of discharge (if made), was not worth the paper it was not written on." ${ }^{, 4}$ The court, in discussing the unenforceability of the prepetition waiver, discussed $\S 524(\mathrm{c})$ as "the only mechanism by which a debtor may 'waive' discharge of a specific debt." ${ }^{, 50}$

40. 246 B.R. at 869 .

41. Id.

42. Id.

43. Id.

44. Id.

45. Id. at 868 .

46. Id. at 872 (stating that "in 11 U.S.C. $\$ 523$, there is no exception to discharge for prepetition attorney's fees").

47. 280 B.R. 347, 349 (Bankr. D.N.J. 2002).

48. Id.

49. Id. at 353 .

50. Id. at 352. Although $\S 524$ (c) can be used to waive the dischargeability of a particular debt, it is important to note that these agreements (referred to as reaffirmation agreements) may only occur postpetition. 11 U.S.C. $\$ 524(c)(1)$ (2006) (stating that the agreement must be entered into before the discharge injunction is operable). 


\section{B. Prepetition Stipulations and Judgments in State Courts}

\section{The Judicial Origins of Stipulations as Relevant to Dischargeability}

In an often-cited footnote, the Seventh Circuit, in Klingman $v$. Levinson, noted: "For public policy reasons, a debtor may not contract away the right to a discharge .... [but] a debtor may stipulate to the underlying facts that the bankruptcy court must examine to determine whether a debt is dischargeable." voluntary agreement between opposing parties concerning some relevant point. " 52 By extension, a stipulation to the underlying facts would be an agreement where the parties negotiate and approve specific relevant facts, which then would be incorporated into a consent decree or judgment. For example, in Klingman, the consent judgment stipulated:

That Defendant [Mr. Levinson], in disregard of his fiduciary duties and obligations as Trustee, has failed to retain and conserve the said trust corpus and income therefrom, but rather, in violation of and disregard of his fiduciary duties and obligations as Trustee, has, through his misappropriation and defalcation, allowed or caused the dissipation and loss of the said trust corpus and income therefrom.

The facts a court could gather from the above stipulation include: (1) Mr. Levinson was a trustee of an express trust; (2) through misappropriation and defalcation Mr. Levinson created a debt that was owed to the beneficiaries; and (3) Mr. Levinson, as trustee, acted in a fiduciary capacity when the debt was created. ${ }^{54}$ A bankruptcy court, armed with the previous stipulations from the prior state court consent judgment, could easily conclude that "defalcation while acting in a fiduciary capacity" has been committed. ${ }^{55}$ In an adversary proceeding, the bankruptcy court can use those specifically stipulated facts to conclude that a debt is nondischargeable because one of the exceptions to discharge is applicable. Although these exceptions encumber a debtor's

51. 831 F.2d 1292, 1296 n.3 (7th Cir. 1987).

52. BLACK'S Law DiCTIONARY 1550 (9th ed. 2009).

53. Klingman, 831 F.2d at 1293.

54. "To establish that a debt is nondischargeable under 11 U.S.C. § 523(a)(4), a creditor must establish that: 1) an express trust existed, 2) the debt was caused by fraud or defalcation, and 3) the debtor acted as a fiduciary to the creditor at the time the debt was created." Id. at 1295.

55. See 11 U.S.C. $§ 523(\mathrm{a})(4)$ (an exception to discharge is available when the debtor, while acting as a fiduciary, commits a fraud or defalcation that causes a debt). 
fresh start, Congress has enacted them for a public policy reason that supersedes the fresh start policy.

\section{Congress Has Determined Certain Debts Are Nondischargeable}

"Generally, all debts are dischargeable in bankruptcy unless specifically excepted by a provision in the Bankruptcy Code." ${ }^{, 56}$ The "exceptions to discharge" alluded to in the previous statement are located in $\S 523(\mathrm{a})$, which lists twenty debts that are considered nondischargeable by Congress. ${ }^{57}$ Originally, the exceptions from discharge were listed in section 17a of the Bankruptcy Act of 1898 and were limited to four categories of debt: taxes owed to the government; debts concerning fraud, false pretenses, false representations or malicious injury to property of another; those not scheduled in the bankruptcy; and debts that were produced by fraud, embezzlement, misappropriation, or defalcation. ${ }^{58}$ Section 523(a) has been amended and expanded over time to include the twenty present grounds under which a debt may become nondischargeable. ${ }^{59}$

"Congress evidently concluded that the creditors' interest in recovering full payment of debts in these categories outweighed the debtors" interest in a complete fresh start." ${ }^{60}$ Further, "Congress did not intend the Code's fresh start policy to provide a haven for the dishonest debtor." 61 Therefore, the exceptions listed in $\$ 523$ (a) are not standard debts, such as an unsecured credit card debt. They have been excluded from discharge because, in many cases, their exception is supported by some public policy rationale, they were enacted to respond to an abuse observed by Congress, or "special interest groups ... lobbied for [the] exception." 62 These exceptions, however, "should not be read more broadly than necessary to effectuate policy.",63

56. Klingman, 831 F.2d at 1296 n.3.

57. See 11 U.S.C. § 523(a)(1)-(19). To clarify, § 523(a) includes twenty grounds because $\S 523(\mathrm{a})(14)$ is split into (14A) and (14B), which are unrelated subsections. Id.

58. 4 LaWrenCE P. King et Al., COllier On BANKRuPTCY II 523.LH[1] (15th ed. rev. 2009).

59. See generally id. (discussing the legislative history of $\S 523$ ).

60. Grogan v. Garner, 498 U.S. 279, 287 (1991) ("The statutory provisions governing nondischargeability reflect a congressional decision to exclude from the general policy of discharge certain categories of debts-such as child support, alimony, and certain unpaid educational loans and taxes, as well as liabilities for fraud.")

61. Lee Blake, Note, St. Laurent v. Ambrose: No Haven for the Fraudulent Debtor, 26 ARIZ. ST. L.J. 561, 566 (1994) (citing St. Laurent v. Ambrose, 991 F.2d 672, 680 (11th Cir. 1993)).

62. WARREN \& WESTBROOK, supra note 8, at 230.

63. Hayhoe v. Cole (In re Cole), 226 B.R. 647, 654 (B.A.P. 9th Cir. 1998). 
Section 523(a)(5), the exception of domestic support obligations, is an easy example to demonstrate the public policy rationale that commonly upholds the subsections of 523(a). ${ }^{64}$ Congress and bankruptcy courts have treated domestic support differently than other types of debt because of "the vulnerability of former spouses and dependents." ${ }^{\circ 5}$ The spousal support exception was first established by the Supreme Court in $1901^{66}$ and was expanded in 1903 to include child support obligations. ${ }^{67}$ These judicial exceptions were incorporated into the Bankruptcy Code under section 17a(2) in 1903. ${ }^{68}$ The longevity of such exceptions "reflect[s] a congressional preference for the rights of spouses to alimony, maintenance or support over the rights of debtors to a fresh start." 69

Each of the remaining $\S 523$ (a) exceptions is also supported by some public policy rationale that outweighs any resulting burden on the debtor postbankruptcy. Some exceptions are included because they are debts owed to the government-such as tax debts, ${ }^{70}$ fines, or penalties ${ }^{71}$ while others acknowledge some culpable conduct-like a debt for money obtained by false pretenses, ${ }^{72}$ willful and malicious injury to another, ${ }^{73}$ and death or personal injury caused by driving while intoxicated. ${ }^{74}$ Despite this procreditor section of the Code, "[a] creditor seeking to have a debt determined to be nondischargeable under section 523 bears the burden of proving each element by clear and convincing evidence." ${ }^{, 75}$

Consequently, a prudent creditor, falling victim to some offense committed by the debtor and understanding that the debtor may file for bankruptcy in the future, may file a lawsuit in state court where the parties stipulate to the underlying facts. In doing so, a creditor should reference $\S 523$ (a) and determine whether any of the twenty subsections

64. 11 U.S.C. § 523(a)(5) (2006) ("A discharge under section $727 \ldots$ does not discharge an individual debtor from any debt for a domestic support obligation . . . .").

65. Austin, supra note 16 , at 1384 .

66. Id. (citing Audubon v. Shufeldt, 181 U.S. 575, 580 (1901)).

67. Id. (citing Dunbar v. Dunbar, 190 U.S. 340, 353 (1903)).

68. 4 KING ET AL., supra note 58, I[ 523.LH[1].

69. Austin, supra note 16, at 1388.

70. 11 U.S.C. $\$ 523(a)(1)$ (2006).

71. Id. $\S 523(\mathrm{a})(7)$.

72. Id. $\$ 523(\mathrm{a})(2)$

73. Id. $\S 523(\mathrm{a})(6)$.

74. Id. $\S 523(\mathrm{a})(9)$.

75. Doug Howle's Paces Ferry Dodge, Inc. v. Ethridge (In re Ethridge), 80 B.R. 581, 586 (Bankr. M.D. Ga. 1987) ("Complaints on dischargeability are strictly construed against creditors because exceptions to dischargeability frustrate the fresh start and rehabilitative purposes of the Bankruptcy Code."). 
are available. If one of the subsections is applicable, the stipulations should be drafted so that each element of the $\S 523$ (a) claim is proved. For example, in continuing with the Klingman facts above, ${ }^{76}$ the creditor purposefully crafted the factual stipulations to prove the elements of a $\S 523(\mathrm{a})(4)$ "defalcation by trustee" claim. ${ }^{77}$ "To establish that a debt is nondischargeable under 11 U.S.C. § 523(a)(4), a creditor must establish that: 1) an express trust existed, 2) the debt was caused by fraud or defalcation, and 3) the debtor acted as a fiduciary to the creditor at the time the debt was created." 78 The factual stipulations in Klingman conclusively established the elements of $\S 523(\mathrm{a})(4)$; therefore, the Seventh Circuit determined that the consent judgment proved the debt was nondischargeable. ${ }^{79}$ In reaching its conclusion, however, the Seventh Circuit also had to conclude that the consent judgment was entitled to collateral estoppel effect. ${ }^{80}$ "Despite [the] guidance by the Supreme Court, there is disagreement among the courts regarding the collateral estoppel effect accorded state court judgments in bankruptcy proceedings involving dischargeability." ${ }^{81}$

\section{Supreme Court Authority on Collateral Estoppel and State Court Judgments}

"[C]ollateral estoppel treats as final only those questions actually and necessarily decided in a prior suit." ${ }^{, 22}$ It has been described as narrower than res judicata, which "forecloses all that which might have been litigated previously." ${ }^{\text {"3 }}$ Fairly limited guidance can be derived from Supreme Court case law regarding issue preclusion and state court judgments in the context of bankruptcy law. The Supreme Court has concluded, in a case unrelated to bankruptcy, "settlements ordinarily occasion no issue preclusion (sometimes called collateral estoppel),

76. See supra text accompanying notes 53-55.

77. 11 U.S.C. § 523(a)(4) (“A discharge under section $727 \ldots$ does not discharge an individual debtor from any debt ... for fraud or defalcation while acting in a fiduciary capacity, embezzlement, or larceny ....").

78. Klingman v. Levinson, 831 F.2d 1292, 1295 (7th Cir. 1987).

79. Id. at 1296 ("The bankruptcy court and the district court therefore properly applied the principle of collateral estoppel and correctly held that the appellant's debt was not dischargeable under 11 U.S.C. § 523(a)(4).”).

80. Id. at 1295 .

81. Id.

82. Brown v. Felsen, 442 U.S. 127, 139 n.10 (1979) (citing Montana v. United States, 440 U.S. 147, 153 (1979)).

83. Id. 
unless it is clear...that the parties intended their agreement to have such an effect." 84 Therefore, it appears that the Court would support the view held by courts that give issue-preclusive effect only upon a finding of intent. ${ }^{85}$ In the context of bankruptcy and dischargeability, the Court has, in dictum, stated that if factual issues previously litigated in state court mirror the analysis applied in the bankruptcy proceeding, the bankruptcy court should give effect to those previous state court determinations. $^{86}$ The Court later stated that "[w]e now clarify that collateral estoppel principles do indeed apply in discharge exception proceedings pursuant to $\S 523(\mathrm{a}) .,{ }^{, 87}$ The courts, however, have come to different conclusions regarding the extent of the previous statement due to the "bankruptcy courts' exclusive jurisdiction in determining dischargeability." 88

\section{The Exclusive Jurisdiction of the Bankruptcy Courts in Nondischargeability}

A stipulation to the underlying facts can occur in one of two possible proceedings. First, a consent judgment may occur in nondischargeability litigation that takes place in bankruptcy court. In such a situation, federal law would apply "regarding the issue-preclusive effect of the judgment." 89 Second, a consent judgment may be entered in a state court proceeding before the debtor has even filed a bankruptcy petition. In this second situation, "the preclusive effect of a state court judgment in a subsequent bankruptcy proceeding is determined by the preclusion law of the state in which the judgment was issued." 90 It is the latter situation that has caused a divergence between the courts.

84. Arizona v. California, 530 U.S. 392, 414 (2000).

85. But cf. Simmons Capital Advisors v. Bachinski (In re Bachinski), 393 B.R. 522, 536 (Bankr. S.D. Ohio 2008) ("The United States Supreme Court has, as a matter of federal law, come down squarely in the 'no-preclusive-effect' camp."). Because the bankruptcy court focuses on the general rule cited by the Court but ignores the earlier qualifying statement regarding the intent of the parties, I consider the Supreme Court to fall within Camp Two rather than Camp One. Id.

86. Brown, 442 U.S. at 139 n.10 ("If, in the course of adjudicating a state-law question, a state court should determine factual issues using standards identical to those of $\S 17$, then collateral estoppel, in the absence of countervailing statutory policy, would bar relitigation of those issues in the bankruptcy court.").

87. Grogan v. Garner, 498 U.S. 279, 284 n.11 (1991).

88. Klingman v. Levinson, 831 F.2d 1292, 1295 (7th Cir. 1987) (comparing different jurisdictions' conclusions regarding collateral estoppel in dischargeability proceedings).

89. Simmons, 393 B.R. at 536.

90. Baldwin v. Kilpatrick (In re Baldwin), 249 F.3d 912, 917 (9th Cir. 2001). 
An emphasis has been placed on the distinction between the two previous situations because generally, "the question of the dischargeability of the debt is not in issue" in the state court proceeding. ${ }^{91}$ Further, the bankruptcy courts are particularly well-suited to determine the dischargeability of debts and to analyze the exceptions enumerated in $\S 523(\mathrm{a}) .^{92}$ However, "[b]efore 1970, the bankruptcy courts had concurrent jurisdiction with the state courts to decide whether debts were excepted from discharge." ${ }^{93}$ But, in practice, the state courts more frequently determined the dischargeability of debts. ${ }^{94}$ When the Bankruptcy Code was amended in 1970, the jurisdiction over certain exceptions was placed exclusively with the bankruptcy courts. ${ }^{95}$ More specifically, under $\S 523(\mathrm{c})(1)$ of the Code, bankruptcy courts have exclusive jurisdiction to determine dischargeability of debts excluded through $\S 523(a)(2),(4)$ and (6). ${ }^{96}$ Section 523(c)(1) states:

Except as provided in subsection (a)(3)(B) of this section, the debtor shall be discharged from a debt of a kind specified in paragraph (2), (4) or (6) of subsection (a) of this section, unless, on request of the creditor to whom such debt is owed, and after notice and a hearing, the court determines such debt to be excepted from discharge under paragraph (2), (4) or (6), as the case may be, of subsection (a) of this section.

The above section requires that a creditor litigate the nondischargeability of those claims in bankruptcy court, and if not challenged during the

91. Saler v. Saler (In re Saler), 205 B.R. 737, 745-46 (Bankr. E.D. Pa. 1997), aff'd, 217 B.R. 166 (E.D. Pa. 1998) (citation omitted).

92. See Klingman, 831 F.2d at 1294 ("The Court further stated that the dischargeability of the debt was an issue that Congress intended the bankruptcy courts, rather than the state courts, to decide." (citing Brown v. Felsen, 442 U.S. 127, 138 (1979))).

93. Grogan v. Garner, 498 U.S. 279, 284 n.10 (1991).

94. Id. ("In practice, however, bankruptcy courts generally refrained from deciding whether particular debts were excepted and instead allowed those questions to be litigated in the state courts.").

95. Id. ("The 1970 amendments took jurisdiction over certain dischargeability exceptions, including the exceptions for fraud, away from the state courts and vested jurisdiction exclusively in the bankruptcy courts."). The purpose of taking jurisdiction away from state courts was "to give those claims to the bankruptcy court so that it could develop expertise in handling them" rather than having state courts with less expertise in federal bankruptcy laws address them. Brown v. Felsen, 442 U.S. 127, 135-36 (1979).

96. See 11 U.S.C. \$ 523(c)(1) (2006).

97. Id.; see also H.R. REP. No. 95-595, at 365 (1977), reprinted in 1978 U.S.C.C.A.N. 5963, 6321; S. REP. No. 95-989, at 80 (1978), reprinted in 1978 U.S.C.C.A.N. 5787, 5865-66 (stating that \$ 523(c)(1) "requires a creditor who is owed a debt that may be excepted from discharge under paragraph (2), (4), or (6) ... to initiate proceedings in the bankruptcy court for an exception to discharge"). 
debtor's case, the debt will be discharged. ${ }^{98}$ Alternatively, both the bankruptcy and nonbankruptcy forums have concurrent jurisdiction regarding the rest of the exceptions to discharge in $\S 523(\mathrm{a}) .{ }^{99}$ Therefore, within those exceptions, creditors "may seek a nondischargeability determination in the bankruptcy court, but are not required to do so."100 As a result, a split has developed between courts regarding the issuepreclusive effect of a judgment entered in a state court proceeding rather than in a bankruptcy court. ${ }^{101}$

\section{The Three Collateral Estoppel Camps}

Although federal appeals courts have generally applied the doctrine of collateral estoppel in dischargeability proceedings, ${ }^{102}$ their conclusions on the matter are not dispositive in the context of bankruptcy. "Under the Full Faith and Credit Act, 28 U.S.C. $\$ 1738$, the preclusive effect of a state court judgment in a subsequent bankruptcy proceeding is determined by the preclusion law of the state in which the judgment was issued." 103 Even though state courts share a common understanding of the meaning, states have widely differing requirements in applying collateral estoppel. ${ }^{104}$ Generally, state courts require that the issue be identical in both proceedings, the issue was actually litigated, and the determination in the state court was necessary and final. ${ }^{105}$ Despite the

98. Whitehouse v. LaRoche, 277 F.3d 568, 576 (1st Cir. 2002).

99. See id. at 578 (finding that when the exception is not one "of the four waivable exceptions to discharge, however, the jurisdiction of the bankruptcy court is concurrent, hence nonexclusive").

100. Id. at 576.

101. Simmons Capital Advisors v. Bachinski (In re Bachinski), 393 B.R. 522, 536 (Bankr. S.D. Ohio 2008) ("The issue of whether consent judgments have issue-preclusive effect has divided the courts ....").

102. See Baldwin v. Kilpatrick (In re Baldwin), 249 F.3d 912, 917 (9th Cir. 2001); Laganella v. Braen (In re Braen), 900 F.2d 621, 630 (3d Cir. 1990); Combs v. Richardson, 838 F.2d 112, 114-15 (4th Cir. 1988); Klingman v. Levinson, 831 F.2d 1292, 1295-96 (7th Cir. 1987); Harold V. Simpson \& Co. v. Shuler (In re Shuler), 722 F.2d 1253, 1256 (5th Cir. 1984); Goss v. Goss, 722 F.2d 599, 604 (10th Cir. 1983); Lovell v. Mixon, 719 F.2d 1373, 1376 (8th Cir. 1983); Spilman v. Harley, 656 F.2d 224, 228 (6th Cir. 1981).

103. In re Baldwin, 249 F.3d at 917; Spartz v. Cornell (In re Cornell), 178 B.R. 45, 47 (Bankr. D. Conn. 1995) ("A number of bankruptcy courts, including the Bankruptcy Appellate Panel of the Ninth Circuit, have recently concluded that state-law, not federal-law, doctrine controls the application of collateral estoppel.").

104. See Bachinski, 393 B.R. at 535 (listing the four requirements under Ohio law for issue preclusion application); In re Baldwin, 249 F.3d at 917-19 (listing the five threshold requirements California imposes plus collateral estoppel application must further public policy considerations); Giaimo v. Detrano (In re Detrano), 222 B.R. 685, 687 (Bankr. E.D.N.Y. 1998) (listing two basic requirements for collateral estoppel).

105. See, e.g., Cobb v. Lewis (In re Lewis), 271 B.R. 877, 877-79 (B.A.P. 10th Cir. 2002). 
previous general principle, "[s]ome courts ... will give no collateral estoppel effect to state court determinations, while other courts do apply collateral estoppel when the issue was litigated previously by the parties." "In fact, the courts have generally fallen into "three camps": one group will not give issue-preclusive effect to state court consent judgments (Camp One), another will give issue-preclusive effect if the parties clearly indicate that the consent judgment is to be given such effect (Camp Two), and the last group generally will give issuepreclusive effect (Camp Three). ${ }^{107}$

\section{a. Camp One: No Issue-Preclusive Effect to State Court Judgments}

A minority of courts will not grant collateral estoppel effect to state court consent judgments. Camp One courts identify two separate grounds to support their reasoning: (1) the bankruptcy courts are given exclusive jurisdiction of certain dischargeability determinations, ${ }^{108}$ and (2) the actually litigated requirement bars collateral estoppel application to consent judgments containing factual stipulations. ${ }^{109}$

First, some courts have narrowly interpreted the jurisdictional difference of $\S 523(\mathrm{c})(1)$ in a way that allows them to discount the authority of any state court judgments containing stipulations to the underlying facts, particularly when $\S 524(\mathrm{a})(2)$, (4) and (6) are involved. ${ }^{110}$ These courts conduct their own review of the facts and determine whether the requirements of that section are present before the dischargeability of a debt is established, giving little, if any, weight to the

106. Klingman, 831 F.2d at 1295.

107. Bachinski, 393 B.R. at 536 (indicating that "three camps" exist regarding consent judgments and issue-preclusive effect).

108. See, e.g., Hayhoe v. Cole (In re Cole), 226 B.R. 647, 653 (B.A.P. 9th Cir. 1998).

109. See, e.g., Word v. Bailey (In re Bailey), 203 B.R. 640, 643 (Bankr. S.D. Ohio 1996).

110. See, e.g., Gregg v. Rahm (In re Rahm), 641 F.2d 755, 757 (9th Cir. 1981) (stating that "prior state court judgment has no collateral estoppel force on a bankruptcy court considering dischargeability unless both parties agree to rest their cases on that judgment"), abrogated by Grogan v. Garner, 498 U.S. 279 (1991); Hayhoe, 226 B.R. at 653 (holding that "the bankruptcy court must make a determination regarding the dischargeability" of the debt "notwithstanding a state court stipulated judgment"); Saler v. Saler (In re Saler), 205 B.R. 737, 741 (Bankr. E.D. Pa. 1997) ("[ [] $\mathrm{n}$ this circuit, it has long been held that prepetition judgments entered by default do not determine, as a matter of issue preclusion ... the nondischargeability of a debt."), aff'd, 217 B.R. 166 (E.D. Pa. 1998). Collateral estoppel also may not be granted to consent judgments by some states for failure to comply with the "actually litigated" requirement. See, e.g., Aslakson v. Anderson (In re Anderson), 49 B.R. 655, 656 (Bankr. W.D. Wis. 1984) (applying the reasoning that "[a] default judgment is not an adjudication on the merits for collateral estoppel purposes" to consent judgments). 
state court judgment. ${ }^{111}$ For example, in Hayhoe v. Cole (In re Cole), the creditor and debtor entered into a prepetition state court stipulated judgment and upon challenge in the bankruptcy dischargeability proceedings, the court disregarded the stipulated judgment. ${ }^{12}$ The court ignored the substantive difference between a waiver and a stipulation and held the state court stipulated judgment regarding dischargeability under $\S 523(\mathrm{a})(2)$ unenforceable. ${ }^{113}$ The court stated that "if the parties stipulated to the underlying facts that support[ed] a finding of nondischargeability, the Stipulated Judgment would then be entitled to collateral estoppel application." 114 But the weight of that statement is severely limited by the court's subsequent declaration that "the state court clearly lacked jurisdiction to litigate a $§ 523(\mathrm{a})(2)$ claim" and any stipulated facts would nevertheless have been irrelevant. ${ }^{115}$

Camp One courts, therefore, distort the meaning of $\S 523(\mathrm{c})(1)$ by very narrowly construing its language to mean that "a duty exists to actually adjudicate dischargeability complaints."116 These courts state the correct intention that "all nondischargeability claims arising under sections 523(a)(2), (a)(4) and (a)(6) must be determined by a bankruptcy court." " They fail to realize, however, that while the state court cannot make a final determination on dischargeability, it can undertake all of the factual analysis involved in a $\S 523(\mathrm{a})(2)$, (4), or (6) claim. ${ }^{118}$

111. Hayhoe, 226 B.R. at 653 ("Thus, the bankruptcy court must make a determination regarding the dischargeability of a $\S 523(\mathrm{a})(2)$ claim notwithstanding a state court stipulated judgment ....”).

112. Id. at 649-50 (affirming the bankruptcy court's decision that "the [s]tipulated [j]udgment was an unenforceable attempt to prospectively waive the bankruptcy discharge").

113. Id. at 656 (stating that the "stipulated facts were nothing more than an invalid agreement that the [d]ebt would be nondischargeable in a future bankruptcy").

114. Id. at 655 .

115. See id. at 655-56 (concluding that because the state court had no jurisdiction over a $\S 523(\mathrm{a})(2)$ claim then the issue could not have been "actually litigated" as required by collateral estoppel requirements).

116. K-Carpet Co. v. Palumbo (In re Palumbo), Bankr. No. 93-61642, Adv. No. 93-6238, 1994 WL 127599, at*3 (Bankr. N.D. Ohio Mar. 24, 1994).

117. Saler v. Saler (In re Saler), 205 B.R. 737, 742 (Bankr. E.D. Pa. 1997) ("A bankruptcy court has exclusive jurisdiction over those claims."), aff'd, 217 B.R. 166 (E.D. Pa. 1998); see also Resolution Trust Corp. v. Roberti (In re Roberti), 183 B.R. 991, 1000 (Bankr. D. Conn. 1995) ("Some courts have found that federal law creates an exception to the application of state collateral estoppel rules when the issue before the bankruptcy court involves dischargeability proceedings that are within the exclusive jurisdiction of the bankruptcy courts, i.e. proceedings under $§ 523(\mathrm{a})(2),(4)$, or (6).").

118. Klemens v. Wallace (In re Wallace), 840 F.2d 762, 764 (10th Cir. 1988) ("Although the bankruptcy court in a dischargeability action under section 523(a) ultimately determines whether or not a debt is dischargeable, we believe that the doctrine of collateral estoppel may be invoked to bar relitigation of the factual issues underlying the determination of dischargeability ...."); Spilman v. Harley, 656 F.2d 224, 227 (6th Cir. 1981) ("[T]hat Congress intended the bankruptcy court to 
Second, Camp One courts confine the application of collateral estoppel only to state court judgments where the issues were "actually litigated." For example, in Word v. Bailey (In re Bailey), an Ohio bankruptcy court applying Nevada law concluded that a consent judgment was not entitled to issue-preclusive effect. ${ }^{119}$ The plaintiffs had hired the debtor "to construct a home for them in Nevada for approximately $\$ 160,000 . " 120$ When the debtor failed to complete the construction of the home, the plaintiffs filed a lawsuit in Nevada state court. ${ }^{121}$ "In Nevada, as well as Ohio, the doctrine of collateral estoppel precludes parties from litigating an issue that existed in a prior action, that was actually litigated in the action, and that was necessary to the determination of the prior action."122 Under Nevada law, a consent judgment is an agreement where the parties do not go to trial but instead agree on certain facts and conclusions. ${ }^{123}$ "In Nevada, consent judgments are not given preclusive effect through the doctrine of collateral estoppel" because the parties never got the chance to litigate the factual issues. $^{124}$

Among the "three camps," the narrow interpretation of the Camp One courts is least desirable because it requires the parties to relitigate all factual claims, even though a state court has already done so. Further, the minority view lacks full consideration of other factors, as demonstrated below in Part IV, because it fails to take into account judicial economy and the potential chilling effect on state judgments that could occur if they are continually overlooked in this matter. ${ }^{125}$

\section{b. Camp Two: Issue-Preclusive Effect if Intent Shown}

The jurisdictions allowing state court consent judgments to be granted issue-preclusive effect generally seek to reduce the repetitive litigation that would occur if bankruptcy courts were required to

\footnotetext{
determine the final result—dischargeability or not—does not require the bankruptcy court to redetermine all the underlying facts.").

119. 203 B.R. 640, 643 (Bankr. S.D. Ohio 1996).

120. Id. at 642 .

121. Id.

122. Id. at 643 .

123. Id.

124. Id. (citing Willerton v. Bassham, 889 P.2d 823, 827 n.6 (Nev. 1995)).

125. See Halpern v. First Ga. Bank (In re Halpern), 810 F.2d 1061, 1065 (11th Cir. 1987) (“[A] chilling effect on consent judgments and settlements might result if the court were to ignore such a clear and unambiguous expression of the parties' intent." (quoting First Ga. Bank v. Halpern (In re Halpern), 50 B.R. 260, 263 (Bankr. N.D. Ga. 1985))).
} 
redetermine all facts previously established in the consent decree. ${ }^{126}$ Camp Two courts are troubled by the conflict of the "actually litigated" requirement of collateral estoppel with consent judgments because the judgments are often reached without litigation. ${ }^{127}$ Although "[i] ssue preclusion is generally inappropriate when the prior judgment was a consent judgment.... [t]he judgment may be conclusive... with respect to one or more issues, if the parties have entered an agreement manifesting that intention." 128 Therefore, Camp Two courts require establishment of each element of collateral estoppel plus a clear intent that the parties desired the consent judgment be given such effect. ${ }^{129}$

In Shaw v. Shaw (In re Shaw), the bankruptcy court applied Michigan law in a case where the plaintiff-wife suffered injuries after the debtor-husband shot her. ${ }^{130}$ The parties entered into a consent judgment in a state court proceeding, the plaintiff-wife agreeing to a $\$ 300,000$ award. ${ }^{131}$ The following year the debtor-husband filed a Chapter 7 bankruptcy petition, and the plaintiff-wife filed an adversary proceeding seeking a nondischargeability determination of the civil remedy based upon the consent judgment. ${ }^{132}$ "Under Michigan law, '[f]or collateral

126. Klingman v. Levinson, 831 F.2d 1292, 1295 (7th Cir. 1987) ("Where a state court determines factual questions using the same standards as the bankruptcy court would use, collateral estoppel should be applied to promote judicial economy by encouraging the parties to present their strongest arguments.").

127. Boddiford v. IRS (In re Boddiford), 312 B.R. 827, 829 (Bankr. W.D. Va. 2004) ("The requirement that the issue be actually litigated does not prevent consent judgments from having collateral estoppel effect. ... In such a situation the intention of the parties is the determining factor in satisfying this requirement.").

128. 18 James WM. Moore et al., Moore’s Federal Practice $§ 132.03$ [2][i][i] (3d ed. 2010).

129. In re Halpern, 810 F.2d at 1065 (stating that "the central inquiry in determining the preclusive effect of a consent judgment is the intention of the parties as manifested in the judgment or other evidence"); Klingman, 831 F.2d at 1296 ("In this situation, it is certainly reasonable to conclude that the parties understood the conclusive effect of their stipulation in a future bankruptcy proceeding."); Metro. Steel, Inc. v. Halversen (In re Halversen), 330 B.R. 291, 303 (Bankr. M.D. Fla. 2005) (stating that "the parties' intent may be established by determining whether the stipulated decision "includes sufficient facts to support a finding that a debt is excepted from discharge" (citation omitted)); Kohlenberg v. Baumhaft (In re Baumhaft), 271 B.R. 517, 521 (Bankr. E.D. Mich. 2001) ("Under Michigan law, consent judgments are normally not given collateral estoppel effect, unless 'the parties have entered into an agreement manifesting an intention that the judgment be conclusive with respect to one or more of the issues[.]" (quoting Mustaine v. Kennedy (In re Kennedy), 243 B.R. 1, 12 (Bankr. W.D. Ky. 1997))); Meggs v. Booth (In re Booth), 174 B.R. 619, 623 (Bankr. N.D. Ala. 1994) ("However, if the parties intend that a consent judgment operates as a final adjudication and make that binding by stipulation of the ultimate facts, then it satisfies the 'actually litigated' element.").

130. 210 B.R. 992, 995 (Bankr. W.D. Mich. 1997).

131. Id.

132. Id. at $995-96$. 
estoppel to apply, a question of fact essential to the judgment must have been actually litigated and determined by a valid and final judgment.",133 Generally, Michigan courts did not accord consent judgments collateral estoppel effect. ${ }^{134}$ The court, however, recognized an exception to the general rule, concluding that if the parties clearly manifested "an intent to be bound by certain facts, collateral estoppel will bar relitigation of those facts." 135 The court concluded that because the consent judgment represented nothing more than a "stipulation or recital" of facts lacking any intent to be bound, collateral estoppel could not properly apply. ${ }^{136}$

Conversely, in Kohlenberg v. Baumhaft (In re Baumhaft), the debtor entered into a settlement agreement that was later filed as a consent judgment in a state court proceeding. ${ }^{137}$ The settlement agreement determined that the debtor "would not challenge the nondischargeability of the Consent Judgment and Supplemental Judgment in any bankruptcy proceeding." 138 Later, when the debtor was forced into a Chapter 7 petition, the other party to the settlement agreement filed an adversary proceeding and contended that the debt was nondischargeable because the consent decree had preclusive effect. ${ }^{139}$ Following the reasoning of the Seventh Circuit, the court concluded that there were no genuine issues of material fact because "the parties did what was required to give their consent judgment collateral effect." 140 The consent judgment specifically stipulated the facts that were required to establish the elements of their claims under $\S 523(\mathrm{a})(2)(\mathrm{A})$ and (B). ${ }^{141}$ The settlement agreement contained explicit statements such as, "I intended to deceive plaintiffs at the time I made the material misrepresentations" and "[p]laintiffs justifiably relied on my material misrepresentations."142 More specifically, as required by Michigan law, the parties signified a clear and unambiguous intent that the debt be nondischargeable. ${ }^{143}$

133. Id. at 998 (quoting Nummer v. Treasury Dep't, 533 N.W.2d 250 (Mich. 1995)).

134. Id. ("A consent judgment is considered a settlement rather than a fully litigated lawsuit, in that "nothing is adjudicated between the two parties to a consent judgment."' (citation omitted)).

135. Id.

136. Id. at 999 .

137. 271 B.R. 517, 519 (Bankr. E.D. Mich. 2001).

138. Id.

139. Id. at 520 .

140. Id. at 522 .

141. Id. at 523 .

142. Id. at 522 .

143. Id. ("The Consent Judgment, Settlement Agreement, and Stipulation of Facts all clearly manifest an intention that the parties be bound by their agreement in a future bankruptcy proceeding."). 
Therefore, the bankruptcy court gave collateral estoppel effect to the stipulated facts in the consent judgment. ${ }^{144}$

\section{c. Camp Three: Issue-Preclusive Effect}

Camp Three courts hold "that where all the requirements of collateral estoppel are met, collateral estoppel should preclude relitigation of factual issues." 145 Unlike courts in Camp Two, these courts require no clear manifestation of intent because they consider stipulations to the underlying facts contained in a consent judgment a "final judgment on the merits." "146 Therefore, the factual issues within the consent decree have been litigated for collateral estoppel purposes. ${ }^{147}$ As long as "the facts admitted in the state court judgment contained all of the elements necessary for a determination of nondischargeability" and each of the elements of collateral estoppel is established, issue preclusion is proper. ${ }^{148}$

In Klemens v. Wallace (In re Wallace), before the debtor filed for bankruptcy, a state court entered a judgment against the debtor for fraud and conversion. ${ }^{149}$ The plaintiff then instituted an adversary proceeding in the debtor's bankruptcy case, seeking a determination that collateral estoppel applied to the state court judgment. ${ }^{150}$ In bankruptcy court, the plaintiff claimed that the state court judgment established the elements necessary to prove the debt nondischargeable under $\S 523(\mathrm{a})(4) .{ }^{151}$ The Tenth Circuit stated the following requirements of collateral estoppel: "(1) the issue to be precluded is the same as that involved in the prior

144. Id. (finding that "the parties did what was required to give their consent judgment collateral estoppel effect").

145. Spilman v. Harley, 656 F.2d 224, 228 (6th Cir. 1981).

146. Rein v. Providian Fin. Corp., 270 F.3d 895, 903 (9th Cir. 2001); see also Am. Equip. Corp. v. Wikomi Mfg. Co., 630 F.2d 544, 546 (7th Cir. 1980) (“'Judicial decrees disposing of issues in active litigation cannot be treated as idle ceremonies denigrating the judicial process." (quoting Wallace Clark \& Co. v. Acheson Indus., Inc., 532 F.2d 846, 849 (2d Cir. 1976))); Pac. Energy \& Minerals, Ltd. v. Austin (In re Austin), 93 B.R. 723, 727 (Bankr. D. Colo. 1988) ("A consent judgment or stipulation and agreement entered as a Court Order, for example, can constitute a final adjudication on dischargeability issues.").

147. Rein, 270 F.3d at 903.

148. Halpern v. First Ga. Bank (In re Halpern), 810 F.2d 1061, 1063 (11th Cir. 1987); see also Klingman v. Levinson, 831 F.2d 1292, 1295 (7th Cir. 1987) (holding that "stipulations in the consent judgment clearly establish that the debt is nondischargeable").

149. 840 F.2d 762, 763 (10th Cir. 1988).

150. Id.

151. Id.; see generally 11 U.S.C. § 523(a)(4) (2006) (listing a debt as nondischargeable if it incurred through embezzlement). 
state action, (2) the issue was actually litigated... and (3) the state court's determination of the issue was necessary to the resulting final and valid judgment." 152 The court concluded that collateral estoppel applied and further determined that "no countervailing statutory policy ... would prevent application of the doctrine." 153 Also, because the state court judgment established each element of the embezzlement claim, the debt was nondischargeable under $\S 523(\mathrm{a})(4) .{ }^{154}$

Additionally, Camp Three courts will, in appropriate circumstances, apply collateral estoppel to default judgments entered in state courts. ${ }^{155}$ For example, a bankruptcy court in the District of Kansas recently determined that a default judgment should be entitled to preclusive effect when the debtor failed to appear in the state civil action. ${ }^{156}$ The debtor issued a check to obtain possession of her vehicle from the plaintiff who had performed repairs. ${ }^{157}$ The issued check was drawn upon the account, which had been previously closed, and therefore insufficient funds existed to pay the check. ${ }^{158}$ The plaintiff filed a civil action, and when the debtor failed to appear, the state court entered a default judgment, specifically concluding that the "defendant obtained goods and services from the plaintiff through fraud." 159 When the debtor filed a voluntary Chapter 7 petition, the plaintiff commenced a dischargeability proceeding in the bankruptcy court and claimed that the state court default judgment established "the fraud discharge exception as provided in $\S 523(\mathrm{a})(2)(\mathrm{A}) ., " 160$ The bankruptcy court concluded that the elements of actual fraud had been established by the state court judgment ${ }^{161}$ and the elements required for collateral estoppel in Kansas were present; ${ }^{162}$

152. In re Wallace, 840 F.2d at 765 .

153. Id. at 764-65.

154. Id. at 765 (listing the elements necessary to establish embezzlement).

155. Bay Area Factors v. Calvert (In re Calvert), 105 F.3d 315, 321 (6th Cir. 1997) ("[C]reditor may utilize collateral estoppel to prevent litigation of the dischargeability of a debt after obtaining a default judgment on claims of fraud in state court."); Tracy's Auto. Corp. v. Sakari (In re Sakari), Ch. 7 Case No. 08-12498, Adv. No. 08-5296, slip op. at 7 (Bankr. D. Kan. Sept. 25, 2009); Spartz v. Cornell (In re Cornell), 178 B.R. 45, 49 (Bankr. D. Conn. 1995).

156. Tracy's Auto. Corp., slip op. at 7-8.

157. Id. at 3 .

158. Id.

159. Id. at 7 .

160. Id. at 5 .

161. Id. at 6 (stating that "the plaintiff has established all of these elements of actual fraud by the requests for admission and the application of collateral estoppel to the state court judgment").

162. Id. at 6-7.

For collateral estoppel to apply under Kansas law, the following elements must be present: (1) a prior judgment on the merits which determined the rights and liabilities of the parties based upon ultimate facts as disclosed by the pleadings and judgment; (2) the 
therefore, the default judgment "preclude[d] relitigation of the fraud issue." $" 163$

Again, the challenge is that most state collateral estoppel doctrines require that the issue have been "actually litigated" 164 in the state court proceeding. These courts are often able to overcome the previous obstacle based upon some failure to act by the debtor, such as not appearing for trial. ${ }^{165}$ Also, courts have indicated that "an actual trial is not imperative."166 Courts, however, will not grant collateral estoppel effect to all default judgments, especially if the judgment resulted from some error or lack of due process. ${ }^{167}$ In K-Carpet Co. v. Palumbo (In re Palumbo), the bankruptcy court refused to apply collateral estoppel effect to a default judgment because the state court had awarded it on the basis of a procedural defect and the parties had presented no factual determinations. ${ }^{168}$ This reasoning is appropriate because a debtor not afforded the opportunity to contribute to the actual litigation of the facts due to no fault of his own would have an unfair judgment forced upon him.

parties must be the same or in privity; and (3) the issue litigated must have been determined and necessary to support the judgment.

Id.

163. Id. at 8 .

164. Spartz v. Cornell (In re Cornell), 178 B.R. 45, 48 (Bankr. D. Conn. 1995) (discussing the collateral estoppel requirements, including "actually litigated and necessarily determined").

165. Id. at 49 ("Although the debtor did not appear in the state proceeding, he was aware of the proceeding, and not precluded by distance, accident or mistake from appearing. He was afforded an adequate opportunity to litigate, and chose not to."); see also Tracy's Auto. Corp., slip op. at 7 (“A default judgment may be given preclusive effect under the doctrine of collateral estoppel. Here, defendant was afforded a full and fair opportunity to litigate the fraud issue in the state court worthless check case.”); Resolution Trust Corp. v. Roberti (In re Roberti), 183 B.R. 991, 1002 (Bankr. D. Conn. 1995) (stating that the appropriate inquiry is whether the party was given an "adequate opportunity" to actually litigate the issues).

166. Austin v. Pac. Energy \& Minerals, Ltd. (In re Austin), 93 B.R. 723, 727 (Bankr. D. Colo. 1988) (stating that the focus is really whether the debtor had an "'opportunity to present his case or litigate the relevant issues"” (quoting Klemens v. Wallace (In re Wallace), 840 F.2d 762, 765 (10th Cir. 1988))).

167. Austin, 93 B.R. at 728 (refusing to grant collateral estoppel effect to "[d]efault judgments which are not entered on consent, or which may be the product of, or tainted by, mistake, fraud, clerical error, lack of due process, denial of debtor's opportunity to a full and fair trial, or other similar infirmity").

168. Bankr. No. 93-61642, Adv. No. 93-6238, 1994 WL 127599, at*3 (Bankr. N.D. Ohio Mar. 24, 1994) 


\section{ANALYSIS}

Up to this point this Comment has offered an overview of two types of prebankruptcy actions that creditors use to overcome the bankruptcy discharge: prepetition waivers and prepetition stipulations. Further, a split in courts has developed regarding the level of enforcement provided to prepetition stipulations. The analysis that follows argues that prepetition waivers are not, and should not, be enforceable and that prepetition stipulations should be enforceable and given collateral estoppel effect. The discussion more fully explains the difference between a waiver and a stipulation and supports the collateral estoppel reasoning of Camp Three courts.

\section{A. Prepetition Waivers of Discharge Are Not Enforceable}

\section{The Bankruptcy Code Does Not Authorize the Use of Prepetition Waivers of Discharge; Therefore, They Are Unenforceable}

As the bankruptcy system developed in the nineteenth century, it saw a series of alternating prodebtor then procreditor legislative acts, until finally reaching the Act of 1898, which represented a balance between the extremes. ${ }^{169}$ In the next one hundred years, the Code saw several amendments - the most recent made in 2005, which "reflect[s] the credit industry's view that bankruptcy law needed to be re-balanced in favor of the creditor interest because it was too often abused by debtors." 170 Despite the purpose of the 2005 Amendments, the Code has continued to be more protective of the debtor in certain contexts, including access to discharge for the consumer debtor. ${ }^{171}$ "The Code is very specific about

\footnotetext{
169. WARREN \& WESTBROOK, supra note 8, at 102.

Essentially, then, the bankruptcy "system" for the first 109 years after the adoption of the Constitution was little more than a series of brief legislative fiats, alternately pro-creditor or pro-debtor, accompanied by a growing awareness that a uniform comprise law would better serve everyone. ...

171. Explicit protections in the Code have been included for the debtor's protection against his own judgment and the pressure of creditors, most notably, the imposition of the automatic stay, the reaffirmation agreement requirements, and the discharge injunction. See, e.g., Nat'l City Bank v. Smyth (In re Smyth), 277 B.R. 353, 356 (Bankr. N.D. Ohio 2001) (stating that one of the purposes of reaffirmation requirements is "to protect debtors from their own bad judgment").
} 
the manner in which a debtor can waive the discharge in bankruptcy."172 Only two methods of waiver of discharge are available to the debtor, and both must occur postpetition. ${ }^{173}$ These two methods of waiver are mutually exclusive; $\S 727(a)(10)$ is applicable to universal discharge, while $\S 524(\mathrm{c})$ is relevant to waiver of discharge of a single debt. ${ }^{174}$

The first method of waiver permitted by the Bankruptcy Code is $\S 727(a)(10)$, which states " $[\mathrm{t}]$ he court shall grant the debtor a discharge, unless - the court approves a written waiver of discharge executed by the debtor after the order for relief under this chapter." ${ }^{175}$ In Rul-Lan v. RulLan (In re Rul-Lan), the creditor-wife argued that the debtor-husband had waived his right to the discharge of debts owed to her when they reached their property settlement. ${ }^{176}$ The court noted that waiver via $\S 727(a)(10)$ was possible if written and if the court granted approval of such waiver after ensuring that the debtor had made a "conscious and informed judgment ... as to the consequences thereof.","177 The court, however, also determined that "the appropriate way to waive discharge as to a specific debt, as opposed to waiving the discharge in the bankruptcy case, is through the use of reaffirmation agreement" and therefore declined to approve the waiver asserted by the creditor-wife. ${ }^{178}$ This analysis of waiver and the limited use of $\S 727(a)(10)$ are accurate because it supports the purpose Congress intended. ${ }^{179}$

172. Rul-Lan v. Rul-Lan (In re Rul-Lan), 186 B.R. 938, 943 (Bankr. W.D. Mo. 1995).

173. See 11 U.S.C. $\S \S 524(c), 727(a)(10)$ (2006); see also Airlines Reporting Corp. v. Mascoll (In re Mascoll), 246 B.R. 697, 706 (Bankr. D.D.C. 2000) ("Congress has provided only two methods for a Chapter 7 debtor to waive the dischargeability of specific debts: (1) by executing a postbankruptcy written agreement, waiving a discharge of all debts, that is approved by the bankruptcy court pursuant to 11 U.S.C. $\$ 727(a)(10)$; or (2) by executing a waiver that satisfies the reaffirmation agreement requirements of 11 U.S.C. § 524(c)."); Hayhoe v. Cole (In re Cole), 226 B.R. 647, 654 (B.A.P. 9th Cir. 1998) (stating that Congress authorized two types of postpetition waivers, including reaffirmation agreements and waiver of discharge in total).

174. See 6 COLlier ON BANKRUPTCY II 727.12 (Alan N. Resnick \& Henry J. Sommer eds., 15th ed. rev. 2009) ("A debtor and creditor should not be permitted to use section 727(a)(10) to avoid the reaffirmation provisions.").

175. 11 U.S.C. $\S 727(a)(10)$ (2006). The language of $\S 727(a)(10)$ is a derivative of the waiver contained in the original Bankruptcy Act of 1898. See The Bankruptcy Act of 1898, § 14a ("That the bankrupt may, before the hearing on such application, waive by writing, filed with the court, his right to discharge.”); 6 COLLIER ON BANKRUPTCY, supra note 174, I[ 727.LH[2][j].

176. 186 B.R. at 943 (stating that the wife argued that the order granting relief from the automatic stay acted as a waiver of discharge).

177. Id. (citing Chilcoat v. Minor (In re Minor), 115 B.R. 690, 693-94 (D. Colo. 1990)).

178. Id.

179. I mention this briefly because there is some confusion regarding the purpose of $\S 727(a)(10)$ by attorneys and a minority of courts. Section 727(a)(10) states: "The court shall grant the debtor a discharge, unless - the court approves a written waiver of discharge executed by the debtor after the order for relief under this chapter." 11 U.S.C. $\$ 727(a)(10)$. From this section several obvious 
Congress's comments regarding $\S 727(a)(10)$ of the Bankruptcy Reform Act of 1978 do not reveal much about the intent they had in enacting that section. ${ }^{180}$ However, the legislative comments surrounding $\S 524(\mathrm{a})$ do help differentiate between the purposes of $\S \S 524(\mathrm{a})(1)$ and 727(a)(10). ${ }^{181}$ Section 524(a)(1) of the Code provides that a discharge will "void[] any judgment ... whether or not discharge of such debt is waived." 182 The legislative history of $\S 524(\mathrm{a})(1)$ reveals that the "whether or not discharge of such debt is waived" language was included "to prevent waiver of discharge of a particular debt, not waiver of discharge in toto as permitted under section 727(a)(9) [sic]." Therefore, the universal waiver of discharge of $\S 727(a)(10)$ is limited to specific circumstances where the parties executed the waiver postpetition, memorialized it in writing, and received court approval. ${ }^{184}$

The second method, and "the appropriate way to waive discharge as to a specific debt," is to enter into a reaffirmation agreement. ${ }^{185}$ In an agreement to reaffirm a debt, "the debtor promises to repay a prepetition debt that would otherwise be discharged at the conclusion of the bankruptcy." 186 A debtor will commonly enter into a reaffirmation agreement to retain nonexempt personal property. This typically involves a secured debt, but reaffirmation applies to unsecured debts as

elements are discernible: the waiver must be executed postpetition, it must be in writing, and the court must approve the waiver. Id. Although the plain language of the statute does not specifically state so, the legislative history of the statute indicates it should only be utilized for waiver of discharge "in toto." See H.R. REP. No. 95-595, at 366 (1977), reprinted in 1978 U.S.C.C.A.N. 5963, 6322; S. REP. NO. 95-989, at 80 (1978), reprinted in 1978 U.S.C.C.A.N. 5787, 5866 (stating that the legislative history reveals that the "whether or not discharge of such debt is waived" language was included "to prevent waiver of discharge of a particular debt, not waiver of discharge in toto as permitted under section 727(a)(9) [sic]").

180. See S. REP. No. 95-989, at 98 (In discussing the nine grounds for denial of discharge, the Senate stated, "The ninth ground is approval by the court of a waiver of discharge.").

181. S. REP. NO. 95-989, at 80 .

182. 11 U.S.C. § 524(a)(1) (similar quoted language is also evident in § 524(a)(2) and (3)).

183. H.R. REP. NO. 95-595, at 366; S. REP. NO. 95-989, at 80 (emphasis added).

184. See 11 U.S.C. $\$ 727(a)(10)$.

185. Rul-Lan v. Rul-Lan (In re Rul-Lan), 186 B.R. 938, 943 (Bankr. W.D. Mo. 1995); see also Jamo v. Katahdin Fed. Credit Union (In re Jamo), 283 F.3d 392, 398 (1st Cir. 2002) (holding that "reaffirmation represents the only vehicle through which an otherwise dischargeable debt can survive"). Reaffirmation agreements are peculiar in the way that they are treated within the Bankruptcy Code. First, for some unknown reason, a reaffirmation agreement is not considered an exception to discharge under $\S 523$ (a) but is instead included in $\S 524$, which is entitled "Effect of discharge." 11 U.S.C. $\S 524$. Yet, even $\S 524(\mathrm{c})$ does not plainly state that it authorizes a "reaffirmation" agreement. Id. The name is actually derived from Rule 4008 of the Federal Rules of Bankruptcy Procedure. That Rule provides that a "reaffirmation agreement shall be filed no later than 60 days after the first date for the meeting of creditors." FED. R. BANKR. P. 4008.

186. BLACK'S LAW DiCTIONARY 1378 (9th ed. 2009). 
well. ${ }^{187}$ Reaffirmation of a secured debt, such as a house or car, is more common because the debtor often desires to keep such property. ${ }^{188}$ Once a debtor reaffirms the debt, the creditor is free to collect because the reaffirmation revives the debt and makes it fully enforceable. ${ }^{189}$

Before the 1898 Amendments to the Code, only common law mandated that "[a] promise to pay a debt that had been discharged in bankruptcy was enforceable."190 Many debtors, therefore, were not obtaining the fresh start that bankruptcy filing was meant to afford due to the aggressive tactics of many creditors. ${ }^{191}$ To combat these tactics, the 1973 Report of the Bankruptcy Commission recommended that discharge serve as a method of extinguishing debts so that debts may not be enforceable due to "a mere reaffirmation." 192 As evidenced by the scope of 11 U.S.C. $\S 524(\mathrm{c})$, Congress did not follow the recommendation of the Bankruptcy Commission but instead caved to external pressure applied by the credit industry. ${ }^{193}$ Reform of the reaffirmation agreement process, however, was again sought after various creditor abuses were exposed, ${ }^{194}$ and the 1997 Bankruptcy Commission recommended the prohibition of agreements to reaffirm

187. See Jamie Beth Feitlin, Note, Reaffirmation Agreements Between Debtors and Creditors: The Past, the Present, \& the Future, 15 N.Y.L. SCH. J. HuM. RTS. 177, 182-86 (1998) (stating various reasons why a debtor may want to reaffirm a debt); Jennifer L. Maffett, Comment, Keeping the Promise of a Fresh Start: Why Congress Should Grant Debtors a Private Right of Action Against Creditors for Abuse of Reaffirmation Agreements, 27 U. DAYTON L. REV. 95, 99-100 (2001) (listing further reasons why a debtor might reaffirm an unsecured debt). For a view that reaffirmation of unsecured debts should be discouraged, see Thomas E. Ray, Debtors Beware: Reaffirmation Agreements Can Be Hard to Rescind, AM. BANKR. Inst. J., Mar. 2001, at 10, 10 (citing In re Nidiver, 217 B.R. 581, 584 (Bankr. D. Neb. 1998)).

188. See Marianne B. Culhane \& Michaela M. White, Debt After Discharge: An Empirical Study of Reaffirmation, 73 AM. BANKR. L.J. 709, 729-31 (1999) (discussing empirical data that found less than ten percent of reaffirmation agreements pertained to unsecured debts).

189. In re Jamo, 283 F.3d at 398; see also WARREN \& WESTBROOK, supra note 8, at 262 ("The consequence of reaffirmation of a secured debt is that debtors sign a legally binding agreement to waive the discharge on a given debt, subjecting themselves once again to losing the collateral and being sued for a deficiency claim ....") (emphasis added).

190. See WARREN \& WeStBROOK, supra note 8, at 259 ("The 1898 Act said nothing about reaffirmations.").

191. See id.; see also REPORT OF THE COMMISSION ON THE BANKRUPTCY LAWS OF THE UNITED STATES, H.R. Doc. No. 93-137, pt. 1, at 177 (1973) (stating: "Commission has been informed that the legislation has achieved its objective in part, but creditors continue to make advantageous use of the financial statements obtained at the time of extending credit by filing or threatening to file applications for determination of nondischargeability against bankrupts and accepting a reaffirmation in settlement of the litigation of threatened litigation.").

192. H.R. DoC. No. 93-137, pt. 1, at 177.

193. WARREN \& WESTBROOK, supra note 8, at 259.

194. See, e.g., id. at 260 (discussing Sears' use of reaffirmation agreements and its failure to comply with the requirements of $\S 524)$. 
unsecured debt and additional restrictions on reaffirmation of secured debt. ${ }^{195}$ In particular, the Commission reprimanded the credit industry for the existence of "rogue reaffirmations" 196 and coercive communications with debtors, which sparked discussions to amend the Code to include a private right of action for debtors against creditors who had abused the reaffirmation process. ${ }^{197}$

In 2005, Congress responded to the concerns of creditor abuse of the reaffirmation process by including additional provisions in the Code applicable solely to reaffirmation agreements. ${ }^{198}$ Consequently, an agreement that fails to make the proper disclosures under each of the $\S 524$ (c) subsections does not strictly comply and is unenforceable as a reaffirmation agreement. ${ }^{199}$ The strict compliance standard is likely derived from the language of $\S 524(\mathrm{c})$, which states that "[a]n agreement between a holder of a claim and the debtor . . . is enforceable ... whether or not discharge of such debt is waived, only if' the subsection requirements are achieved. ${ }^{200}$ The additional conditions of $\S 524(\mathrm{c})$ and the strict compliance standard ensure that the debtor receives a fresh start and makes an educated, independent, and voluntary decision to reaffirm a debt. ${ }^{201}$

Because Congress specifically enacted two postpetition methods of waiving dischargeability of debts, the lack of legislation regarding prepetition waivers cannot be an oversight. ${ }^{202}$ If prepetition waivers were considered valid, the bankruptcy courts would be creating an exception that is not enumerated by Congress within the Bankruptcy Code. ${ }^{203}$ Congress's decision not to validate prepetition waivers is appropriate because it limits the encroachment creditors may have on the

195. Id. at 261.

196. Culhane \& White, supra note 188 , at 718 .

197. See Maffett, supra note 187, at 105.

198. WARREN \& WESTBROOK, supra note 8, at 261.

199. See, e.g., Doug Howle's Paces Ferry Dodge, Inc. v. Ethridge (In re Ethridge), 80 B.R. 581, 586 (Bankr. M.D. Ga. 1987) (holding the consent judgment unenforceable as a reaffirmation agreement because it failed to include a statement that the agreement could be rescinded pursuant to $\S 524(c)(2))$.

200. 11 U.S.C. § 524(c) (2006) (emphasis added) (requiring that the agreement be voluntary, it not impose an undue hardship, the debtor understand the legal effects of the agreement, the debtor has not rescinded the agreement by a specified date, and the individual have an opportunity for a hearing).

201. Nat'1 City Bank v. Smyth (In re Smyth), 277 B.R. 353, 356 (Bankr. N.D. Ohio 2001).

202. See Hayhoe v. Cole (In re Cole), 226 B.R. 647, 653-54 (B.A.P. 9th Cir. 1998) ("Congress's failure to authorize prepetition waivers of discharge, while at the same time authorizing certain prepetition waivers of discharge ... must be viewed as intentional.").

203. Id. at 653 . 
dischargeability of debts. This Comment supports the postpetition methods to waive discharge because they are properly tailored to uphold the purpose of the Bankruptcy Code while also protecting "debtors from their own misjudgments." ${ }^{204}$ A waiver under $§ 727(a)(10)$, for example, must be approved by the bankruptcy court, and generally debtors must prove they have made an informed decision regarding the effect of such a waiver. $^{205}$ Further, $\S 524(\mathrm{c})$ has extensive requirements for a debtor to reaffirm. $^{206}$ It is obvious that Congress drafted $\S 524(\mathrm{c})$ so that the debtor is fully apprised of the consequences of reaffirmation and is not unduly pressured to reaffirm by the creditor. ${ }^{207}$ Even though the debtor has the option to reaffirm, the debtor has "some protection against his own (potentially) short-sighted decisions." 208 In contrast, a prepetition waiver is often entered into before bankruptcy is even contemplated, and, therefore, the debtor will have no understanding of the effects such an agreement may have in the future. Prepetition waivers should be unenforceable, as the majority of courts have determined, ${ }^{209}$ because they

204. Douglas G. Baird, Discharge, Waiver, and the Behavioral Undercurrents of DebtorCreditor Law, 73 U. CHI. L. REV. 17, 21 (2006). "Legal rules protect us from ourselves by insisting that legal formalities accompany decisions where we are prone to make systematic misjudgments." Id. at 18; see also Thomas H. Jackson, The Fresh-Start Policy in Bankruptcy Law, 98 HARV. L. REV. 1393 , 1403 (1985) ("Bankruptcy's fresh-start policy . . provides substantially broader protection to debtors" than other policy options that were considered).

205. In deciding whether to approve a waiver of discharge, some courts will only do so if the debtor made a conscious and informed decision regarding the waiver. See, e.g., Rul-Lan v. Rul-Lan (In re Rul-Lan), 186 B.R. 938, 943 (Bankr. W.D. Mo. 1995) (stating that "[s]uch waiver "must present a conscious and informed judgment by the debtor as to the consequences thereof" (quoting In re Mapother, 53 B.R. 433, 435-36 (Bankr. W.D. Ky. 1985))).

206. See 11 U.S.C. $\$ 524(c)$ (2006); see also supra note 200 and accompanying text.

207. S. REP. No. 95-989, at 80 (1978), reprinted in 1978 U.S.C.C.A.N. 5787, 5866; see also In re Catron, 186 B.R. 194, 196 (Bankr. E.D. Va. 1995) ("It is evident from the literal language of the statute that 'Congress was greatly concerned that a debtor waiving dischargeability of a particular debt be afforded the procedural protections provided in $\S 524(\mathrm{c})$, regardless of any pre-existing agreement as to nondischargeability." (quoting Chilcoat v. Minor (In re Minor), 115 B.R. 690, 695 (D. Colo. 1990))).

208. Jamo v. Katahdin Fed. Credit Union (In re Jamo), 283 F.3d 392, 398 (1st Cir. 2002). At first glance $\S 524(c)$ of the Bankruptcy Code seems like the valid and immutable discharge waiver creditors had long desired, but further investigation reveals a major caveat-the reaffirmation agreement can be rescinded by the debtor. Section 524(c)(4) allows a debtor to rescind a reaffirmation agreement before discharge or within sixty days of filing the agreement, whichever is later. 11 U.S.C. $\$ 524(c)(4)$.

209. See, e.g., Hayhoe v. Cole (In re Cole), 226 B.R. 647, 652 (B.A.P. 9th Cir. 1998); Cotten v. Cotten (In re Cotten), 318 B.R. 583, 587 (Bankr. W.D. Okla. 2004) ("Certainly, waivers of a discharge have been held to be unenforceable.”); Lewis v. Trump (In re Trump), 309 B.R. 585, 593 (Bankr. D. Kan. 2004) ("[P]repetition agreements to waive the benefits of a bankruptcy discharge are void, and this Court is not bound by this language."); Hester v. Daniel (In re Daniel), 290 B.R. 914, 920 (Bankr. M.D. Ga. 2003) (“"Further, courts have not permitted pre-petition waivers of protection afforded by a bankruptcy case to be self-executing." (quoting In re Shady Grove Tech 
overly burden the debtor's chance at a fresh start. This burden is in direct conflict with the long-established purpose of the Bankruptcy Code. Further, contrary to its postpetition counterparts, prepetition waivers offer debtors no protective measures from creditors and the debtors' own bad judgment.

\section{Prepetition Waivers of Discharge Are Unenforceable Because They Violate the Fresh-Start Purpose of the Bankruptcy Code}

"[M]odern bankruptcy law is premised on the idea that a fresh start should be available to honest debtors, even when their own bad judgment caused their financial difficulties." 110 As expressed in Part II, the idea of a "fresh start" is a central purpose of the American bankruptcy system, and this Comment does not question its precedent. ${ }^{211}$ Instead, the heart of this discussion is based upon two opposing public policies: the longstanding American tradition of freedom to contract versus the freshstart purpose of the Bankruptcy Code. ${ }^{212}$ In Klingman v. Levinson, the Seventh Circuit stated in dictum that "[f]or public policy reasons, a debtor may not contract away the right to a discharge in bankruptcy." 113 That statement has been extended and interpreted by courts to mean that prepetition waivers of discharge, whether for a single debt or all debts, "are void, offending the policy of promoting a fresh start for individual debtors." 214 In Doug Howle's Paces Ferry Dodge, Inc. v. Ethridge (In re Ethridge), for example, the parties entered into a consent judgment,

Ctr. Assoc. Ltd. P'ship, 216 B.R. 386, 389 (Bankr. D. Md. 1998), opinion supplemented, 227 B.R. 422 (Bankr. D. Md. 1998))); Doug Howle's Paces Ferry Dodge, Inc. v. Ethridge (In re Ethridge), 80 B.R. 581, 586 (Bankr. M.D. Ga. 1987) (stating "that the provisions of the consent judgment which pertain to the waiver of Defendant's right to discharge are void").

210. Baird, supra note 204, at 31; see also Maffett, supra note 187, at 130 ("The law should enable the bankruptcy system to promote some success of allowing debtors a fresh start from which they can rebuild and return as dependable and valuable consumers in the economy of the country.").

211. See Charles G. Hallinan, The "Fresh Start" Policy in Consumer Bankruptcy: A Historical Inventory and an Interpretive Theory, 21 U. RICH. L. REV. 49, 53-89 (1986) (discussing the evolution of the fresh start). But see Katherine Porter \& Deborah Thorne, The Failure of Bankruptcy's Fresh Start, 92 CoRNELl L. REv. 67, 67 (2006) (discussing whether consumers are financially rehabilitated after bankruptcy).

212. See Ethridge, 80 B.R. at 586 (following the argument posited by the plaintiff); see also Thomas H. Jackson, The Fresh-Start Policy in Bankruptcy Law, 98 HARV. L. REV. 1393, 1404 (1985) (stating that "making discharge nonwaivable raises troubling implications" such as contravention of the freedom to contract).

213. 831 F.2d 1292, 1296 n.3 (7th Cir. 1987).

214. Marra, Gerstein \& Richman v. Kroen (In re Kroen), 280 B.R. 347, 351 (Bankr. D. N.J. 2002) (citing Hayhoe, 226 B.R. at 651); see also Herz v. Steil (In re Steil), Bankr. No. 05-0207, Adv. No. 05-9108, 2006 WL 2662694, at*3 (Bankr. N.D. Iowa Aug. 14, 2006) (adopting the reasoning from In re Kroen). 
requiring that the debtor "would not seek to discharge the judgment" and "the judgment would not be dischargeable in bankruptcy." 215 The plaintiff explicitly argued "that a party may agree to forego a legal right, [and] that such an agreement creates a binding contract." 216 The court, however, concluded that the fresh start in bankruptcy would be upheld over the freedom to contract. ${ }^{217}$

The view expressed by the bankruptcy court in Ethridge has been widely accepted by other courts, ${ }^{218}$ and despite the limitation on the freedom to contract, the view represents, on balance, the best outcome. If, for example, the courts chose instead to uphold the freedom to contract, creditors would habitually include prepetition waivers in every agreement. "[T]hen creditors would essentially have the power to nullify the fresh start provided by the Bankruptcy Code."219 Debtors would leave "bankruptcy owing nearly as much as they did before they filed,",220 so the entire purpose of the Code would be undermined. Therefore, for public policy reasons, prepetition waivers of discharge are unenforceable.

\section{B. Prepetition Stipulations Involving Discharge Exceptions Should Be Entitled to Collateral Estoppel Effect}

The discussion above established that prepetition waivers of discharge are unenforceable. But isn't a prepetition stipulation in essence a prepetition waiver? Although some courts have failed to see a distinction, ${ }^{221}$ this Comment considers a prepetition stipulation different than a prepetition waiver because it requires additional factual determinations. ${ }^{222}$ It should be noted, however, that a general stipulation

215. 80 B.R. at 585.

216. Id. at 586 .

217. Id. (discussing the right of a party "to forego a legal right" but determining that in these circumstances such a decision would be "contrary to the spirit of the Bankruptcy Code").

218. See generally Lichtenstein v. Barbanel, 161 F. App'x 461, 467 (6th Cir. 2005); Hayhoe, 226 B.R. at 654; Barnett v. Rich (In re Rich), 401 B.R. 281, 288 (Bankr. S.D. Ohio 2009); Kroen, 280 B.R. at 351; In re Nieves, 246 B.R. 866, 872 (Bankr. E.D. Wis. 2000); Chilcoat v. Minor (In re Minor), 115 B.R. 690, 694-96 (Bankr. D. Colo. 1990).

219. Ethridge, 80 B.R. at 586.

220. WARREN \& WESTBROOK, supra note 8, at 259 (discussing how "debtors are not like new babies" but are often "tangled with some of the same debt that sank them the first time around").

221. See, e.g., Hayhoe, 226 B.R. at 653 ("Consequently, a state court stipulated judgment where the debtor waives his right to discharge is unenforceable as against public policy.").

222. Shaw Steel, Inc. v. Morris (In re Morris), Nos. 97 B 39268, 98 A 00121, 1998 WL 355510, at *8 (Bankr. N.D. Ill. June 30, 1998).

An agreement to waive the dischargeability of a debt is not enforceable as a matter of 
regarding dischargeability, without stipulation to the underlying facts, is not enforceable under the analysis offered here. For example, in Simmons Capital Advisors, Ltd. v. Bachinski (In re Bachinski), a debtor and creditor entered into a consent judgment for $\$ 220,000$ that contained the following language: "Defendants acknowledge that the Amended Complaint includes allegations of fraud, and acknowledge and agree that the obligations imposed upon Defendants by this agreement shall be nondischargeable in any bankruptcy, regardless of the party that is brought into bankruptcy and regardless of whether the bankruptcy is voluntary or involuntary." $" 23$ Although the stipulation stated that it was based upon allegations of fraud, such a bare assertion will not constitute a sufficient determination of fact by the state court to conclude that the debt was of the nature required by $\S 523(\mathrm{a})(2)$, (4) or (6). ${ }^{224}$ Consequently, it is not enough to simply state that the debt is nondischargeable as a matter of law. ${ }^{225}$ Also, it is insufficient to specifically state in the consent judgment the section under which the debt would be nondischargeablefor instance, "this debt is nondischargeable under section 523(a)(4)."226 As a result of such inadequate drafting, in dischargeability proceedings the bankruptcy court will refuse to grant any collateral estoppel effect and will "make independent findings regarding the factual basis underlying the initial incurring of the debt" because the state judgment does not contain the requisite factual specificity. ${ }^{227}$ Such bare assertions do not contain factual stipulations; therefore the judgment is in essence a prepetition waiver of discharge masquerading as a prepetition stipulation. This type of state court judgment should not be given collateral estoppel effect and is not supported by this Comment.

The analysis that follows supports the view expressed by Camp Three courts, which generally grant collateral estoppel effect to state court judgments if the state law elements of collateral estoppel are established. Camp Three is favorable because it grants issue-preclusive effect to state court judgments more liberally than the other two camps,

public policy. This is distinct from a factual stipulation entered into between parties in a prior piece of litigation which may properly serve as the basis for application of the doctrine of collateral estoppel or issue preclusion in later litigation between them. Id.

223. 393 B.R. 522, 529 (Bankr. S.D. Ohio 2000)

224. Id. at 537.

225. Doug Howle's Paces Ferry Dodge, Inc. v. Ethridge (In re Ethridge), 80 B.R. 581, 585 (Bankr. M.D. Ga. 1987) (noting that the stipulation merely stated "the judgment would not be dischargeable in bankruptcy").

226. Giaimo v. Detrano (In re Detrano), 326 F.3d 319, 322 (2d Cir. 2003).

227. Ethridge, 80 B.R. at 587. 
and Camp Three courts will, when appropriate, grant collateral estoppel effect to default judgments. Further, recall that the factual stipulation must not only establish the collateral estoppel requirements but must also establish the elements of the $\S 523$ (a) claim to be enforceable. With those conditions met, three main reasons are offered for granting collateral estoppel effect to state court judgments that contain stipulations to the underlying facts.

\section{Collateral Estoppel Promotes Public Policy Considerations Such as} Judicial Economy

"Applying collateral estoppel is logically consistent with the Supreme Court's decision in Brown and the exclusive jurisdiction of the bankruptcy courts while at the same time encouraging judicial economy." 228 If the parties know that the consent judgment they reach in the state court proceeding will be entitled to collateral estoppel effect, they will "present their strongest arguments" at trial and the record, if reviewed by the bankruptcy court, will support the outcome. ${ }^{229}$ Because state courts have concurrent jurisdiction to determine the dischargeability of seventeen out of twenty exceptions, ${ }^{230}$ there is no reason to suspect "that the bankruptcy court will be any more fair or accurate than the state court in the determination of the facts." ${ }^{\text {"231 }}$ Therefore, allowing a bankruptcy court to rely on a state court determination permits the bankruptcy court to conserve time and energy. ${ }^{232}$ Also, not only will the bankruptcy courts conserve resources but the parties will also be prevented from enduring "vexatious litigation." 233 The public policy justification for economy is also especially relevant to debtors who have already sustained a financial burden and do not want to exit the bankruptcy process with attorney's fees compromising their fresh start.

228. Spilman v. Harley, 656 F.2d 224, 227 (6th Cir. 1981).

229. Klingman v. Levinson, 831 F.2d 1292, 1295 (7th Cir. 1987) (citing Spilman, 656 F.2d at 228). Spilman explained that "[c]ollateral estoppel is applied to encourage the parties to present their best arguments on the issues in question in the first instance and thereby save judicial time." 656 F.2d at 228

230. See 11 U.S.C. § 523(a)(1)-(19) (2006).

231. Spilman, 656 F.2d at 228.

232. Baldwin v. Kilpatrick (In re Baldwin), 249 F.3d 912, 920 (9th Cir. 2001) ("Relying on the state court's determination allows the bankruptcy court to conserve judicial resources.").

233. Id. at 919-20 (stating that collateral estoppel protects "litigants from harassment by vexatious litigation" (internal quotation marks omitted)); Cobb v. Lewis (In re Lewis), 271 B.R. 877, 883 (B.A.P. 10th Cir. 2002) ("The purpose of the collateral estoppel doctrine is to protect parties from multiple lawsuits, prevent the possibility of inconsistent decisions, and conserve judicial resources.”). 


\section{Collateral Estoppel Avoids a Potential Chilling Effect on State Court} Consent Judgments

Bankruptcy courts should grant state court stipulated judgments collateral estoppel effect to prevent a chilling effect. If, instead, the majority of courts applied the Camp One reasoning-consent judgments should not be given issue-preclusive effect-it would be unlikely that state courts would expend much time and energy in considering bankruptcy dischargeability considerations. "Under such circumstances...'[a] chilling effect on consent judgments and settlements might result if the court were to ignore [] a clear and unambiguous expression of the parties' intent,",234 favoring the enforcement of the consent judgment. Such an effect could have two consequences. First, the bankruptcy courts would have an increase in dischargeability proceedings because parties would likely ignore the concurrent jurisdiction of the states and instead file a dischargeability motion in bankruptcy court, if available. Second, disregard of factual stipulations agreed upon by the parties and incorporated in a state court consent judgment may "do violence to judicial finality." 235 After completion of the state court proceeding, the conclusiveness of the judgment would be indefinite. ${ }^{236}$ If the defendant debtor soon after filed for bankruptcy, the matter would have to be settled again with a consent judgment entered in bankruptcy court-if the debtor was willing-or the plaintiff might have to prove the debtor's guilt, making the prior state court judgment valueless. To maintain the consistency and integrity of state court judgments, bankruptcy courts should afford those judgments collateral estoppel effect. ${ }^{237}$

\section{The Consequences of Granting Collateral Estoppel Effect to the Discharge Exceptions Are Negligible}

Promotion of the liberal view of Camp Three will not cause any farreaching effects. If a creditor and debtor stipulate to facts that have no relation to one of the discharge exceptions, the stipulation will have no

234. Halpern v. First Ga. Bank (In re Halpern), 810 F.2d 1061, 1065 (11th Cir. 1987) (quoting First Ga. Bank v. Halpern (In re Halpern), 50 B.R. 260, 263 (Bankr. N.D. Ga. 1985)).

235. Halpern, 50 B.R. at 262.

236. Cobb, 271 B.R. at 883 ("The purpose of the collateral estoppel doctrine is to protect parties from multiple lawsuits, prevent the possibility of inconsistent decisions, and conserve judicial resources.").

237. In re Baldwin, 249 F.3d at 920 (discussing the public policy behind collateral estoppel). 
effect. It will be an unenforceable prepetition waiver that the majority of courts have held violate public policy. ${ }^{238}$ A properly executed stipulation to the underlying facts in a state court proceeding, however, does not run afoul the fresh-start purpose of the Code because the stipulations are limited in number and subject by $\S 523$ (a). Even though creditors may succeed in these situations more often than debtors, the nature of the debts is such that debtors should be held accountable for their payments. $^{239}$

The only real consequence that application of the Camp Three view will have is that a few more state court consent judgments will be granted issue-preclusive effect. Because Camp One represents the view of the minority, the change to a more liberal view by those courts will be of small significance. Also, courts currently following the view expressed in Camp Two will have to change very little about their jurisprudence. Indeed, the courts will follow the same analysis but will grant collateral estoppel effect if the state court collateral estoppel requirements are present and the state court consent judgment pleads the elements of the $\S 523$ (a) claim. The focal point of the analysis is no longer the parties' intent. Therefore, the debtor is adequately protected through the limited availability of the circumstances when a stipulation may be used and even further protected by the requirements that the parties must establish before collateral estoppel is available. Consequently, all bankruptcy courts should adopt the liberal view of Camp Three courts, which grant collateral estoppel effect to state court judgments when the elements are present and do not require any special indication of intent.

\section{CONCLUSION}

The bankruptcy discharge is a highly guarded privilege from which consumer debtors greatly benefit. It represents a fundamental purpose of the American bankruptcy system, which allows the debtor to have a fresh start at life, free from prior financial encumbrances. Although bankruptcy law often relieves debtors from their own bad financial judgments, the law also protects debtors who encounter substantial misfortunes, such as extensive medical bills or rising debts due to job loss. To use the bankruptcy process and be afforded a discharge, the unfortunate debtor need only be honest. The Bankruptcy Code has been

238. See sources cited supra note 211.

239. See supra note 60. 
developed to protect the honest debtor and, in some circumstances, will dismiss a debtor who has filed for bankruptcy in bad faith. Despite the preference for honest debtors, a debtor who has been less than an upright citizen before filing for bankruptcy can use the Code. The fresh start of this debtor, however, will be limited because Congress has determined that certain debts are not dischargeable and many of those debts are incurred through some kind of culpable conduct. Beyond those exceptions, the bankruptcy court will discharge the debtor's personal liability for all remaining prepetition debts. The bankruptcy discharge, therefore, represents an extremely prodebtor practice. It is of no surprise then that creditors have made various prepetition attempts to limit the effect of the bankruptcy discharge so that less loss is transferred to them.

One way creditors try to lower their risk is by requiring debtors to sign a prepetition waiver of discharge. As evident from this Comment, prepetition waivers of a specific debt or all debt are unenforceable. Congress permits only two types of waiver and both must occur postpetition. First, the debtor may make a universal waiver of discharge pursuant to $\S 727(a)(10)$. If the debtor enters into a universal waiver, the court will not discharge any of the prepetition debts. Therefore, the use of universal waivers is rare because they require judicial approval and they defeat the fresh-start purpose of bankruptcy. The second type of postpetition waiver that Congress permitted allows a debtor to waive discharge of a specific debt under $\S 524(\mathrm{c})$. The debtor will enter into a reaffirmation agreement with the creditor, which causes the personal liability attached to the debt to survive discharge. The Bankruptcy Code, however, carefully controls the use and form of reaffirmation agreements. Since Congress established two ways to waive debts postpetition, courts conclude by negative implication that prepetition waivers are unenforceable. But the conclusion is also supported by the fresh-start purpose of bankruptcy.

The other method creditors use prepetition is a stipulation to the underlying facts in a state court judgment. Although a stipulation closely resembles an unenforceable prepetition waiver because it can occur in state court before the debtor has filed a petition, the two are substantively different. Factual stipulations are limited to the discharge exceptions listed in $\S 523(\mathrm{a})$, which have been enacted for various public policy reasons and are construed narrowly against the creditor. Therefore, for the bankruptcy court to enforce, the stipulation must establish each element of the dischargeability exception. Conversely, a blanket provision in a consent decree that a debt is nondischargeable under $\S 523$ is in essence a prepetition waiver and is unenforceable. The discussion further compared and analyzed the collateral estoppel effect granted by 
state courts to these stipulations, which in general fall into one of three camps. Collateral estoppel effect that is generally applied and does not require any specific intent is preferred. This view is favorable because it upholds the value of state court judgments, encourages judicial economy, and allows a creditor to know that the debt is nondischargeable, bringing finality to the process. 